\title{
LOSS OF CALMODULIN ACTIVITY IN CARDIAC SARCOPLASMIC RETIOULUM AFTER ISCHEMIA
}

Mila B. Turla, Margaret E. Gnegy, Susan Epps, and Marshal Shlafer*

Department of Pharmacology, The University of Michigan Medical School, Ann Arbor, Michigan 48109-0010

Received June 11, 1985

Experiments were designed to evaluate whether cardiac ischemia affected the subcellular distribution of calmodulin activity. Major cellular fractions (nuclei, mitochondria, sarcoplasmic reticulum and cytosol) were isolated from globally ischemic hearts by differential centrifugation. Ischemia did not affect calmodulin activity in cell fractions other than sarcoplasmic reticulum, which showed a consistent and complete loss of activity. This site-specific loss of calmodulin activity may be one mechanism by which ischemia induces contractile dysfunction.

C 1985 Academ1c Press, Inc.

\section{$\mathrm{Ca}^{2+}$ sequestration by cardiac sarcoplasmic reticulum (SR) via a $\left(\mathrm{Ca}^{2+}-\mathrm{Mg}^{2+}\right)$-ATPase $\mathrm{Ca}^{2+}$ transport system plays an important role in} terminating contraction and eliciting relaxation (1). Loss of myocardial contractility due to ischemia is accompanied by decreased $\mathrm{Ca}^{2+}$ uptake by the SR (2-4), but the molecular events respansible for ischemia-induced impairments are still unclear. Calmodulin (CaM), a $\mathrm{Ca}^{2+}$-binding protein $(5,6)$, stimulates the rate of ATP-dependent $\mathrm{Ca}^{2+}$ transport by cardiac SR (7-10). In the presence of ATP, $\mathrm{Ca}^{2+}$ and $\mathrm{Mg}^{2+}$, the terminal phosphate of ATP is cleaved, forming a $\mathrm{Ca}^{2+}$-dependent phosphoprotein intermediate of $\mathrm{Ca}^{2+}$ transport located on the cytosolic face of the SR membrane. As the SR sequesters $\mathrm{Ca}^{2+}$, the intermediate decomposes yielding inorganic phosphate. CaM may enhance the rate of phosphoprotein dephosphorylation (1) or may stimulate a $\left(\mathrm{Ca}^{2+}-\mathrm{CaM}\right)$-dependent membrane-bound protein kinase that increases $\left(\mathrm{Ca}^{2+}-\mathrm{Mg}^{2+}\right)-A$ TPase activity and $\mathrm{Ca}^{2+}$ uptake. This increase in ATPase activity is associated with the phosphorylation of a membrane-bound protein, phospholamban $(8,11)$.

*To whom all correspondence should be addressed. 
The results show a significant decrease in CaM activity in cardiac SR after two hours of normothermic global ischemia, suggesting the involvement of CaM in the contractile dysfunction commonly seen after myocardial ischemia.

\section{MATERIALS AND METHODS}

Chemicals and Reagents

Tris-hydroxymethylaminamethane (Tris) and ammonium acetate were obtained from Schwarz-Mann. Cyclic 3',5'-AMP, 5' nucleotidase and dithiothreitol were from Sigma Chemical Company. Diethylaminoethyl cellulose resin (DE23) was obtained from Whatman. $\left[{ }^{3} \mathrm{H}\right] c \mathrm{MMP}$ (specific activity $23 \mathrm{Ci} /$ mol) was from New England Nuclear. Other chemicals were reagent grade from Baker Chemical Company.

\section{CaM-deficient Phosphodiesterase (PDE)}

CaM-deficient PDE was prepared by the method of Klee and Krinks (12). In brief, supernatant from centrifuged brain homogenate was subjected to ammonium sulfate precipitation and then DEAE ion exchange chromatography on DE23 resin. This PDE was stimulated 5-10 fold by $500 \mathrm{ng}$ of CaM.

\section{Purified CaM}

CaM was purified by the method of Dedman et al. (13) and Klee (14). In brief, brain or testicular tissue was heated to denature and precipitate most enzymatic activity. The supernatant was then purified by sequential liquid chromatography on DE23 resin, Ultragel and then phenyl-Sepharose gel. The CaM appeared as a single 17,000 molecular weight band on a sodium dodecylsulfate-polyacrylamide electrophoretic gel using coomassie Blue stain.

\section{Preparation of Heart Samples}

Rabbits were stumned by a sharp blow to the head, exsanguinated and the hearts were removed immediately. The hearts were then perfused for $30 \mathrm{~min}$ by a modified Langendorff technique with physiologic saline solution as described by Shlafer et al. (4). The hearts were then made globally ischemic (complete cessation of perfusion) for $2 \mathrm{hr}$ at $370^{\circ} \mathrm{C}$. They were not reperfused. This protocol induces severe ventricular contracture and almost complete loss of active force generation. Velocities and maximal amounts of ATP-dependent $\mathrm{Ca}^{2+}$ accumulation by SR isolated from these hearts are significantly depressed. Control (nonischemic) hearts were perfused for $2.5 \mathrm{hr}$ with oxygenated perfusate. Both control and ischemic hearts were simultaneously homogenized (Tekmar Tissuemizer ${ }^{R}$ ) in a medium containing $0.25 \mathrm{M}$ sucrose, 5 $\mathrm{mM} \mathrm{NaN}_{3}, 2 \mathrm{mM}$ ascorbic acid and $5 \mathrm{mM}$ Tris-Cl ( $\mathrm{pH} 6.8$ at $4{ }^{\circ} \mathrm{C}$ ). Major organelles (nuclei, mitochondria and SR) were isolated by differential centrifugation (15). The mitochondrial fraction was washed twice. The initial SR fraction was extracted with $0.6 \mathrm{M} \mathrm{KCl}$ in $20 \mathrm{mM}$ Tris-maleate ( $\mathrm{pH}$ 6.8 ), resedimented, and the final pellet was resuspended in $50 \mathrm{mM} \mathrm{KCl}$ in $20 \mathrm{mM}$ Tris-maleate.

CaM-stimulated PDE Assay

The crude homogenate, nuclear pellet and mitochondrial pellet were resuspended in the original homogenizing medium to which Lubrol PX $(1 \% \mathrm{v} / \mathrm{v})$ was added. The protein concentration of each heart fraction was determined (16) using bovine serum albumin as a standard. All samples were then diluted with PDE buffer (100 $\mathrm{mM}$ Tris $\mathrm{HCl}$, $\mathrm{pH}$ 8; $10 \mathrm{mM} \mathrm{MgSO} 4,30 \mathrm{uM} \mathrm{CaCl} 2$ and 92.6 $\mathrm{mg} / \mathrm{l}$ dithiothreitol) to a protein concentration of 0.5 to $3.0 \mathrm{ug} / \mathrm{ul}$. Samples were assayed for CaM-stimulated PDE activation by incubation (100 ul final assay volume) in PDE buffer, 1.7 ug of purified PDE and 20 ul of heart sample. This procedure is a modification of the method of Filburn and Karn (17). Reactions were started by adding $\left[{ }^{3} \mathrm{H}\right]$ cAMP $(20$ uM final concentration; 
$0.2 \mathrm{uCi}$ /assay). The reactants were incubated at $370 \mathrm{C}$ for $10 \mathrm{~min}$; reactions were stopped by heating at $1000 \mathrm{C}$ for $1 \mathrm{~min}$. The product of the reaction (5'AMP) was further incubated at $370^{\circ} \mathrm{C}$ for $30 \mathrm{~min}$ with $20 \mathrm{ul}$ of 5 'nucleotidase $(0.5 \mathrm{units} / \mathrm{ml})$ to convert 5 'AMP to adenosine, with no effect on unreacted CAMP. This reaction was stopped using $400 \mathrm{ul}$ of $0.18 \mathrm{M}$ ammonium acetate buffer ( $\mathrm{pH} \mathrm{4}$ ). Tritiated adenosine was separated from unreacted cAMP by neutral aluminum column chromatography ( $3 \mathrm{~g}$ ICN dry neutral alumina washed with $0.18 \mathrm{M}$ ammonium acetate buffer, $\mathrm{pH} 4$ ). Samples were eluted into counting vials with $1.5 \mathrm{ml}$ of $0.18 \mathrm{M}$ ammonium acetate buffer. Twelve ml Aquasol or the equivalent was added and samples were counted in a liquid scintillation spectrometer $\left({ }^{3} \mathrm{H}\right.$ counting efficiency was $34 \%$ ). Purified CaM (20 to $120 \mathrm{ng}$ ) was used to construct a standard curvc. Calmodulin activity of the fractions was determined (ng $\mathrm{CaM} / \mathrm{ug}$ protein) using the linear portion of the standard curves. AnY effects of Lubrol PX on activation of PDE were determined and taken into account.

\section{RESULTS AND DISCUSSION}

The effect of $2 \mathrm{hr}$ of normothermic global ischemia on CaM activities of cardiac subcellular fractions is illustrated in Figure 1. The CaM activity in SR isolated from ischemic hearts was essentially zero, compared to $1.05 \pm 0.1$ ng CaM/ug protein in the corresponding fraction of nonischemic control hearts $(P<0.01)$. The SR was the only major cell fraction in which CaM activity was affected significantly by ischemia. The greatest CaM activity, $6.00 \pm 0.68$ $\mathrm{ng} / \mathrm{ug}$, was found in the cytosol. Cytosolic CaM activity in ischemic hearts was $5.91 \pm 0.55 \mathrm{ng} / \mathrm{ug}$. Mitochondria from nonischemic hearts contained $0.57 \pm$ $0.08 \mathrm{ng} / \mathrm{ug}$, which was the lowest activity of the major cell fractions. CaM activity of the mitochondrial fraction from ischemic hearts was $0.49 \pm 0.14$ ng/ug.

The cause of this decreased SR-associated CaM activity after ischemia is unknown. It may reflect ischemia-induced in situ CaM inactivation,

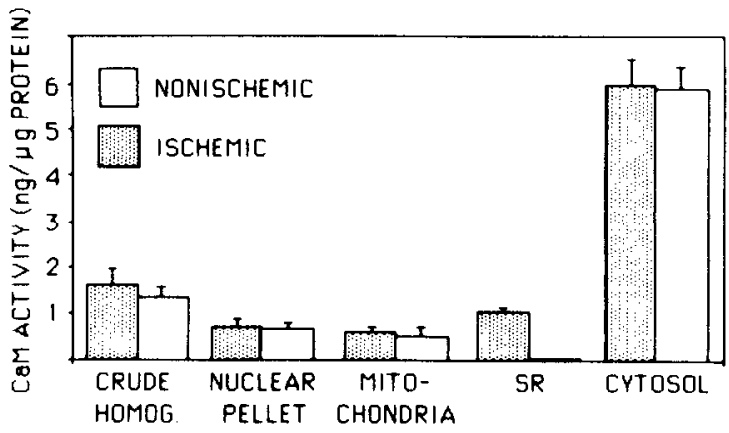

Figure 1. Calmodulin activity of various fractions of nonischemic $(n=7)$ and ischemic $(n=7)$ hearts. Values shown are arithmetic means +1 S.E.M. *Significant difference $(P<0.01)$. 
dissociation of CaM from the SR membrane, or altered binding affinity of CaM that renders it vulnerable to dissociation during homogenization or centrifugation. Any explanation would nonetheless suggest site-specific alterations of CaM activity or binding from its native state in nonischemic heart. Although global ischemia was uscd as a model to provide relatively homogeneous ischemic damage to facilitate tissue sampling, comparable or more prolonged regional ischemia due to coronary artery thrombosis occurs in vivo and also produces severe contractile dysfunction. The impaired contractility and underlying changes of subcellular $\mathrm{Ca}^{2+}$ transport may be due in part to loss of CaM from the SR.

\section{REFERENCES}

1. Katz, S. (1980) Ann. N.Y. Acad. Sci. 356, 267-278.

2. Muir, J.R., Dhalla, N.S., Ortega, J.M., and Olson, R.E. (1979) Circ. Res. 26, 429-438.

3. Nayler, W.J., Stone, J., Carson, V., and Chipperfield, D. (1971) J. Mol. Cell. Cardiol. 2, 125-143.

4. Shlafer, M., Kane, P.F., and Kirsh, M.M. (1982) J. Thorac. Cardiovasc. Surg. 83, 830-839.

5. Cheung, W.Y. (1980) Science 207, 19-27.

6. Klee, C.B. and Vanaman, T.C. (1982) Adv. Protein Chem. 35, 213-321.

7. Katz, S. and Remtulla, M.A. (1978) Biochem. Biophys. Res. Commun. 33, 1373-1379.

8. LePeuch, C.J., Haiech, J., and Demaille, J.G. (1979) Biochemistry 18, 5150-5157.

9. Kirchberger, M.A. and Antonez, T. (1982) J. Biol. Chem. 257, 5685-5691.

10. Plank, B., Pifl, C., Hellmann, G., Wyskorsky, W., Hoffmann, R., and Suko, J. (1983) Eur. J. Biochem. 136, 215-221.

11. Kirchberger, M.A. and Tada, M. (1976) J. Biol. Chem. 251, 725-729.

12. Klee, C.B. and Krinks, M.H. (1978) Biochemistry 17, 120-126.

13. Dedman, J.R., Potter, J.D., Jackson, R.L., Johnson, J.D., and Means, A.R. (1977) J. Biol. Chem. 252, 8415-8422.

14. Klee, C.B. (1977) Biochemistry 16, 1017-1024.

15. Harigaya, S. and Schwartz, A. (1969) Circ. Res. 25,781-794.

16. Lowry, O.H., Rosebrough, N.J., Farr, A.L., and Randall, R.J. (1951) J. Biol. Chem. 193, 265-267.

17. Filburn, C.R. and Karn, J. (1973) Anal. Biochem. 52, 505-516. 